\title{
Improving the Quality of Religious Islamic Education Learning through Collaborative Learning Approach in SMP Al-Muslimin Pandan District Tapanuli Tengah
}

\author{
Ellisa Fitri Tanjung \\ Doctoral Student of Islamic Religious Education Program \\ University of Muhammadiyah Malang \\ ellisafitritanjung@gmail.com
}

\begin{abstract}
The product quality of education is determined by teachers in learning processes underlying curriculum (official), which results of highly dependence on what is done by the teacher in the classroom (actual). Atmosphere of learning and teaching was directed so that learners can develop her potential. Previous learning approach which concentrates on the teacher (teacher-centered) to the student-centered approach to learning (studentcentered), it takes master-teacher teaching methods, classroom management, and the ability to motivate students. Mastery of the teaching method is far more important than the provision of subject matter (alThoriqoh ahamm min al-hymn). The problems related to this study include: (1) description of the educational approach that can improve the quality of teaching Islamic education in junior high school students of class VII in Al-Muslimin Pandan Central Tapanuli. (2) collaborative learning education approach can improve the quality of teaching Islamic education in junior high school students of class VII Al-Muslimin Pandan. This study applies the quality approach and collaboration from any action researchers. The study was carried out in SMP AlMuslimin Pandan Central Tapanuli. Data source were derived from class VII. The subject of study comprised 30 students.
\end{abstract}

Keywords: the quality of learning, islamic religious education, collaborative learning.

\section{INTRODUCTION}

Education is a conscious and deliberate effort to create an atmosphere of learning processes so that learners are actively developing the learning potential to have the spiritual power of religion, self-control, personality, intelligence, noble character, skills, society, nation and state [1].

Allah has given two tools to every human being that can be used by humans to learn the mind and heart. As stated by Salleh on Islamic education teaching and learning methods, according to Allah, have provided in human of two important tools of learning, namely; mind (aql) and liver (qalb). However, he thinks between the two is used in many cases in the Islamic education system, that is mind (aql), while the heart (qalb) is ignored [2]

The product quality of education is determined by teachers in learning processes underlying curriculum (official), which results of highly dependence on what is done by the teacher in the classroom (actual). The quality of learning is also influenced by the attitude of creative teachers to select and implement various approaches or methods of learning. Therefore, the teaching profession requires a creative attitude and a desire to exercise the creativity and improvisation[3],

On the other words, teachers should always foster and develop creative attitudes in learning management, for example, in selecting and using a variety of techniques, approaches, methods and media of learning in accordance with the conditions of the students and the learning objectives of Islamic education. Teaching is not just a knowledge transfer from a teacher to students, but also to help students build their own knowledge through the power of the phenomenon and objectivity [4],

Teachers need to keep practicing to be confident in thinking and acting while showing a good attitude in accordance with the values of Islam purely as an example to the students. Such criteria illustrate that the selection of teacher candidates is not only seen from his academic performance, but also more importantly in the independence and good personality [5], The most important thing in achieving the learning objectives of Islamic education should be able to deliver students to reach three aspects. First, the aspect of faith that covers all the pillars of faith. Both aspects of worship cover all the pillars of Islam. Third, the moral aspect covers the entire akhlakul karimah[6],

In Keller and Fischer's research on the importance of teacher content knowledge (pedagogical) guides children to motivate student interest and student achievement. What teachers do, how they behave, and how they manage and interact with students, all depend on the skills of teachers. The majority of the difference in interest and student achievement lies in the classroom. Participants in today's classrooms with a wide range of differences (e.g. regarding ethnicity, inclusive education, and socio-economic status), each student is treated the same as their needs, and this is one of the challenges 
faced by the teachers. Definitely, the teachers should have a broad knowledge of learning and always encouraged to develop the professionalism of teachers and attention which is systematically developing their pedagogical knowledge [7].

One effort to create an atmosphere of learning that allows students to communicate well is to use an educational approach centered on the student (studentcentered approaches). The approach of learning centered is based on collaborative learning. Learning collaborative learning is a form of active learning.

Active learning is a form of interaction between students and teachers in which the two sides interact with one another in the classroom; students are not passive listeners, but active participants in the process. Using modern educational technology and active learning in environmental education is very important, because it can be used to advance effective training and professional orientation of students [8]

Mell Silberman (2001) in his book Active Learning. 101 Active Learning Strategies, says that one of the best ways to develop active learning is learning projects that were completed in the small group of students. Supporting fellow educators, diversity of views, knowledge and expertise, help provide a collaborative learning to become a valuable part of learning climate in class. Collaborative learning is a process of learning in groups, where each student to convey and share information, experience, attitudes, opinions, abilities, and skills to jointly improve the understanding of the entire group. Collaborative learning is based on the premise that learning should encourage and help students engage directly and build knowledge so as to achieve a deep understanding.

Collaborative learning includes social skills and learning abilities. It combines three concepts, namely the responsibility of the individual (individual accountability), group profit (group benefits), and achieving the same success (equal achievement of success) [9].

The purpose of the collaborative learning is to increase student interaction in understanding a task. Active learning is: a. each student obtained instructional methods that engage students in classroom activities rather than passively listen to lectures, b. classroom assessment involves a variety of activities ranging from designing tests, pencils, paper and performance measurement to vote, communicate the results of the assessment, and use it when making decisions, c. effectively designed to monitor and influence the development of students' thinking processes, inquiry skills, attitudes towards science and learning behavior which requires on-going assessment forms that are integrated into everyday life [10],

The location of this research in the junior school AlMuslim. The subjects Pandan for Islamic Education in general are using conventional learning, which can be seen from the results of observations and interviews conducted with several teachers. Based on observations of researchers, students in class $\mathrm{X}$ in the junior $\mathrm{Al}$ -
Muslimin Pandan tend to be passive and rarely ask the teacher or classmates whom are not able to give an answer when the teacher asked. Developing students' skills in defining, analyzing arguments, assessing, clarifying any questions or being exposed of the material submitted to a teacher during the learning process, it is seen from the interaction of students with teachers who are still dominated by teachers, students rarely ask, less respond to what taught by a teacher, and when the teacher asked the students are not able to provide answers. Thus, when looking at collaborative learning surplus, it is expected to improve the quality of Islamic education learning outcomes of students. Therefore, the purpose of research is to determine the effect of the application of methods of collaborative learning to the improvement of the Islamic education quality in class VII, Al-Muslimin, Pandan, Central Tapanuli district.

\section{METHOD}

This study is a descriptive qualitative study aimed at describing or illustrating the phenomena that are and will be investigated. Subject and other research data source is Islamic education teacher and several students of class VII SMP Al-Muslimin Pandan, Tapanuli middle. Data collection methods used include direct observation with regard to human behavior which shows the real condition in the field, interviews and documentation. This study using qualitative data analysis was illustrated numerically.

\section{RESULT}

Achieving the goal of basic education according to the subject matter of classroom learning activities, SMP Al-Muslimin Pandan using strategies of various collaborative learning invite students to discuss classroom tasks, so that the students do not get bored with the method.

Applying the method of learning in groups importantly cultivates an attitude of mutual cooperation, collaboration and responsible in terms of accomplishing the task. This opinion is also supported by [11] mentioning the importance of group goals and individual responsibility in helping and encouraging one another to perform a maximum learning effort.

\section{Student-created methods Studies (Students' Work Case Study)}

The case study is considered as the best current method of learning. Case study is one type of case discussions on the issue regarding the phenomenon of the real situation or a case demanding activities and lessons which offer solutions to anticipate situations in the near future. The techniques used in this method can take cases that are in their environment, or if possible, take the case of the students themselves [12].

This method is included in the method that uses several kinds or types of methods i.e. lecturing and discussion. The use of the lecturing can convey the 
teaching-learning ways to start activities to students by using words. Discussion is learning a case when students have it solved by individual and group discussion techniques. The method, for example, allows students to look for important information or news through social media to be used as ingredients in the study. A case study of students' work is often used by the teacher to solve learning problems. In addition to this learning activity, students may use life problems/ cases that exist in their everyday life, such as a private matter, a family, friends, neighbors or even the most recent issues in social media, such as television, radio or newspapers. This way of learning is undertaking a process of scientific thinking.

This method is applied into learning activities to deal with various issues, whether it is a matter of personal, family or group. The focus is the investigation and discovery learning that is basically solving the learning problems. This method is expected to train students to think and act creatively, solve problems facing realistically. On top of the learning process, the students are expected to develop progress of thinking and act appropriately when solving learning problems.

The procedures designed by the teachers of Islamic education are applied into the following students' case study learning method using a step-by-step implementation:

1. Teacher assigns students to look for the problem (the case) in their personal life or group.

2. The class is divided in pairs or threes in one group, the rest of the other groups can analyze and discuss the issues. For example, one case by a group that is despicable behavior: insubordinate children against parents.

3. The appointed member of each group in the case study is studying a topic, and the member starts to identify it in the real situation or example that illustrates the topic.

4. Teachers give sufficient time for each pair or group to develop their case to be discussed, or a problem to be solved. Then each couple or group directed in detail to summarize their case studies that lead to the cause of children against parents.

5. When the discussion is finished students are required per group or partner to present their report in front of the class in rotation by allowing one of them to lead the discussion of cases.

After teachers of Islamic education subjects implement the teaching method of collaborative learning, the learning result of junior high students' learning behavior of Al-Muslimin Pandan may show differences. The students, in one hand, learn more spirit, passion and excitement during the learning of Islamic Education. On the other hand, the students enthusiastically learn task questions posed by the teacher. Overall, this learning process may influence students' learning attitudes on Islamic education learning outcomes proved in student achievement related to subjects of Islamic education in particular and other subjects in general.

\section{CONCLUSION}

Based on the research results, there are two significant effects of the application of collaborative learning to improve the quality of Islamic education teaching in class VII Al-Muslimin Pandan. Firstly, Collaborative Learning methods increase learning Islamic education on achievement in school and outside of school. Secondly, students are encouraged to develop wisdom in religious fields, which train the students' performance in school. Among junior high schools, alMuslimin Pandan is competitive at the district / municipal, provincial and even national level.

\section{REFERENCES}

[1] P. R.I, Undanng-Undang Republik Indonesia No. 20 tahun 2003 tentang Sistem Pendidikan Nasional. Jakarta: Restindo Mediatama, 2003.

[2] M. S. Salleh, "Strategizing islamic education," Int. J. Educ. Res., vol. 1, no. 6, hal. 1-14, 2013.

[3] S. S. Nana, Prinsip dan Landasan Pengembanagan Kurikulum. Jakarta: P2LPTK, 1983.

[4] J. Muliawan, Pendidikan Islam Integratif. Yokyakarta: Pustaka Pelajar, 2005.

[5] M. A. Lubis, "Effective implementation of the integrated Islamic education," Eff. Implement. Islam. Educ., vol. 5, no. 1, hal. 59-68, 2015.

[6] P. daulay Haidar, Pendidikan Islam Dalam Sistem Pendidikan Nasional di Indonesia. Jakarta: Kencana Perenada Media Group, 2007.

[7] M. M. Keller, K. Neumann, dan H. E. Fischer, "The impact of physics teachers' pedagogical content knowledge and motivation on students' achievement and interest," J. Res. Sci. Teach., vol. 54, no. 5, hal. 586-614, 2017.

[8] A. M. Zedan, M. Y. Z. B. M. Yusoff, dan M. R. Bin Mohamed, "An Innovative Teaching Method in Islamic Studies: The Use of PowerPoint in University of Malaya as Case Study," Procedia Soc. Behav. Sci., vol. 182, hal. 543-549, 2015.

[9] L. Campbell. M, Metode Praktis Pembelajaran: Berbasis Multiple Intelegences. Depok: Instuisi Press, 2001.

[10] J. M. Mantikayan, T. Mantoro, dan H. Mohammed, "The Effects of Audience Response Systems on ActiveLearning," no. Ical, hal. 78-84, 2012.

[11] E. S. Robert, Cooperative Learning theory, Research and Practice, Allyn \& Bacon A simon \& Schuster Company. Singapore, 2008.

[12] S. Mell, Active Learning: 101 Strategi Pembelajaran Aktif. yogjakarta: Pustaka Insan Madani, 2005. 